medRxiv preprint doi: https://doi.org/10.1101/2021.03.06.21252603; this version posted March 8, 2021. The copyright holder for this preprint

(which was not certified by peer review) is the author/funder, who has granted medRxiv a license to display the preprint in perpetuity.

\title{
BNT162b2 COVID-19 mRNA vaccine elicits a rapid and synchronized antibody response in
}

\section{blood and milk of breastfeeding women}

Michal Rosenberg Friedman ${ }^{1,2^{+}}$, Aya Kigel ${ }^{3 \dagger}$, Yael Bahar ${ }^{3}$, Yariv Yogev ${ }^{1,2}$, Yael Dror ${ }^{3}$, Ronit Lubetzky $^{2,4}$, Ariel Many ${ }^{1,2}$, Yariv Wine ${ }^{3 *}$

${ }^{1}$ Department of Obstetrics and Gynecology, Lis Maternity \& Women's Hospital, Tel Aviv Sourasky Medical Center, Tel Aviv, Israel

${ }^{2}$ Sackler Faculty of Medicine, Tel Aviv University, Tel Aviv, Israel

${ }^{3}$ The Shmunis School of Biomedicine and Cancer Research, The George S. Wise Faculty of Life Sciences, Tel Aviv University, Tel Aviv, Israel

${ }^{4}$ Department of Pediatrics, Dana Dwek Children's Hospital, Tel Aviv Sourasky Medical Center, Tel Aviv, Israel

${ }^{\dagger}$ These authors contributed equally to this work

*Corresponding author, Email: yarivwine@tauex.tau.ac.il

Keywords: SARS-CoV-2, BNT162b2 COVID-19 mRNA vaccine, antibody, breastmilk, humoral immunity 
medRxiv preprint doi: https://doi.org/10.1101/2021.03.06.21252603; this version posted March 8, 2021. The copyright holder for this preprint (which was not certified by peer review) is the author/funder, who has granted medRxiv a license to display the preprint in perpetuity.

We describe the dynamics of the vaccine-specific antibody response in the breastmilk and serum in a prospective cohort of ten lactating women who received two doses of the Pfizer-BioNTech BNT162b2 COVID-19 mRNA vaccine. The antibody response was rapid and highly synchronized between breastmilk and serum, reaching stabilization 14 days after the second dose. The predominant serum antibody was IgG. The response in the breastmilk included both IgG and IgA with neutralizing capacity.

The accelerated COVID-19 vaccination campaign in Israel was initiated in December 2020 and currently nearly $50 \%$ of the adult population have received the Pfizer-BioNTech BNT162b2 COVID-19 mRNA vaccine (mRNA vaccine) ${ }^{1}$. The vaccine campaign initially targeted high-risk populations ( $\geq 60$ years old and healthcare providers) ${ }^{2}$ and was soon expanded to lactating women ${ }^{3}$. Notwithstanding the reported high efficiency of this vaccine $^{4}$ and evidence for the generation of viral-specific antibodies in the breastmilk of women with COVID-195-7, there are no available data on its efficiency in lactating women or its potential benefits in neonatal protection via the passive transfer of vaccine-specific antibodies in breastmilk ${ }^{8}$. The current knowledge gap is preventing global health authorities from making concrete recommendations regarding vaccination during lactation.

We describe the dynamics of the breastmilk and serum antibody response in a prospective cohort of ten lactating healthcare providers, mean age 34.6 (range 30-38), who received the first dose of the mRNA vaccine approximately five months postpartum (mean 154 days, range 68-382) and the second dose 21 days later (Supplementary Table 1).

To obtain calculated endpoint titers for IgG and IgA in breastmilk and serum dyads against the SARS-CoV-2 spike and receptor binding domain (RBD) proteins, serial dilution ELISAs were run on days 7 and 14 after the first (designated 1D7 and 1D14, respectively) 
medRxiv preprint doi: https://doi.org/10.1101/2021.03.06.21252603; this version posted March 8, 2021. The copyright holder for this preprint (which was not certified by peer review) is the author/funder, who has granted medRxiv a license to display the preprint in perpetuity. It is made available under a CC-BY-NC-ND 4.0 International license.

and second (designated 2D7 and 2D14, respectively) vaccine doses (Supplementary Fig. 1 and Supplementary Fig. 2). We found that the spike (Fig. 1) and RBD-specific

(Supplementary Fig. 3) antibody responses in breastmilk and serum were synchronized for $\operatorname{IgG}$ and $\lg A$.

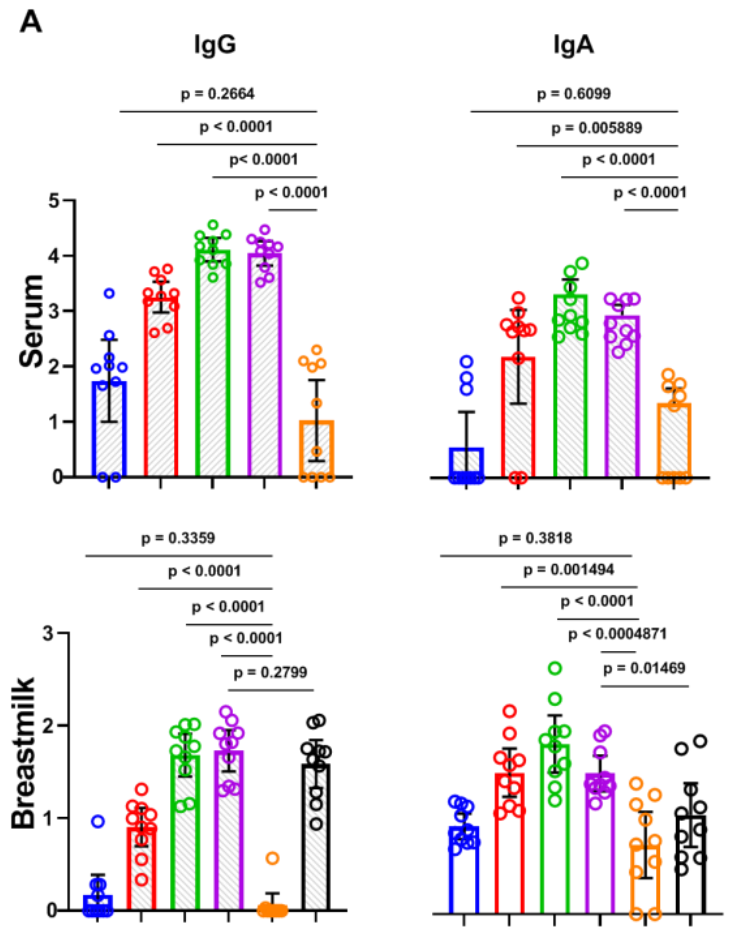

B

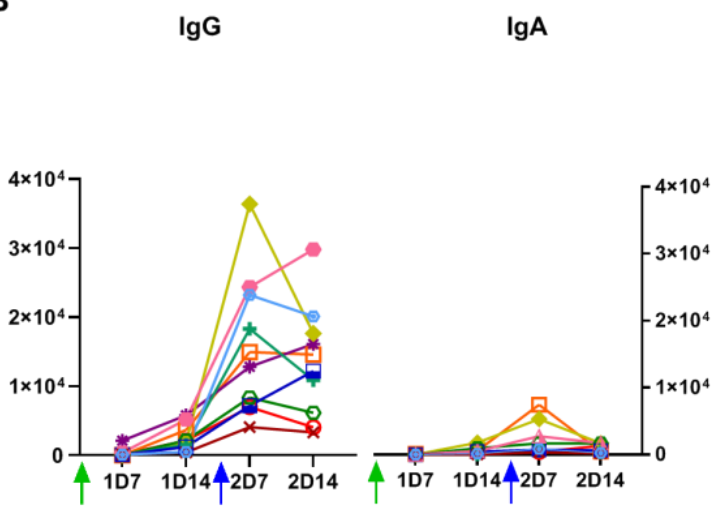

1D7 1014 207 2014 Control 프

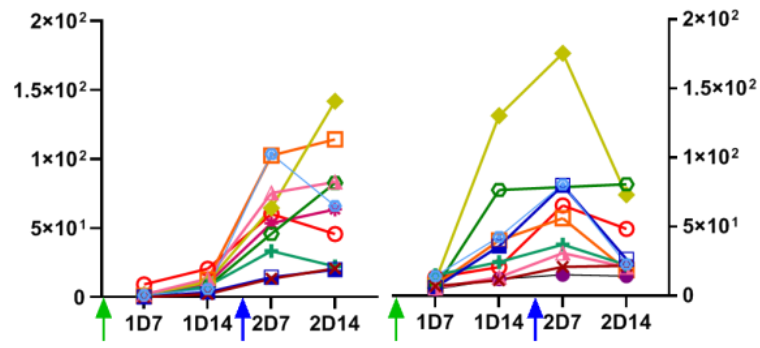

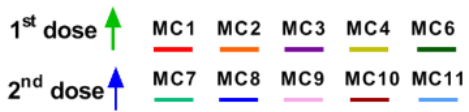

Fig. 1 | Endpoint titers of spike-specific IgG and IgA antibodies in breastmilk and serum of mothers vaccinated with the Pfizer-BioNTech vaccine $(n=10)$. (A) Endpoint titers were interpolated by applying a four-parameter logistic curve on reciprocal dilution series for IgG and IgA for all serum and lactoserum samples at four time points (by color) and for tetanus toxoid (TT)-specific IgG and IgA in breastmilk. P values were determined with an unpaired, two-sided Mann-Whitney U-test after applying Bonferroni correction; $\mathrm{P}<$ 0.0083 was considered statistically significant. Results are presented as geometric means and 95\% confidence intervals. Y-axis units are endpoint titers on a logarithmic scale. Control serum $(n=10)$ and lactoserum samples $(n=10)$ were obtained before the COVID-19 pandemic. (B) Endpoint titers per participant, each shown in a different color. Green and blue arrows indicate the time points of administration of the first $(\mathrm{t}=0)$ and second $(\mathrm{t}=21)$ vaccine doses, respectively. Y-axis units are endpoint titers on a linear scale. 
medRxiv preprint doi: https://doi.org/10.1101/2021.03.06.21252603; this version posted March 8, 2021. The copyright holder for this preprint (which was not certified by peer review) is the author/funder, who has granted medRxiv a license to display the preprint in perpetuity. It is made available under a CC-BY-NC-ND 4.0 International license.

At 1D7, the vaccine-specific endpoint titers had not increased significantly above the titers in the control group (pre-pandemic serum and lactoserum), and the first significant increase in antibody titers was evident at 1D14. The upward trend peaked at 2D7, followed by a slight decrease in titers at 2D14.

Since all participants had received the tetanus, diphtheria, acellular pertussis (Tdap) vaccine during the third trimester ${ }^{9}$, we were able to compare the breastmilk endpoint titers for IgG and IgA elicited by the mRNA vaccine at 2D14 to tetanus toxoid (TT)-specific antibody titers in the same participants. We found that the spike- and RBD-specific IgG and IgA titers did not differ significantly from the TT-specific antibody titers.

Thereafter, we evaluated the vaccine-specific IgG/IgA ratio in breastmilk and serum. The serum antibody response was dominated by $\lg G$, and the $\lg G / \lg A$ ratio was significantly higher in serum than in breastmilk at all four time points (Supplementary Fig. 4). The $\operatorname{lgG} / \lg A$ ratio in breastmilk indicated that the vaccine-specific response was not dominated by $\lg A$, but rather that the $\operatorname{lgG} / \lg A$ ratio increased over time, as previously described following respiratory syncytial virus immunization ${ }^{10}$.

To better understand the temporal dynamics of the antibody response following mRNA vaccination, we calculated the fold-change of endpoint titers at each time point compared to the preceding time point. The vaccine-specific IgG and IgA titers in breastmilk and serum increased substantially 7 days following each vaccine dose, and the increase in fold-change halted 14 days following the second dose. Noteworthy, for spike- and RBDspecific IgA in breastmilk, the fold-change at 2D14 fell below 1, indicating declining IgA levels at that time point (Supplementary Fig. 5). Calculation of fold-change above the endpoint titer at 1D7 (Fig. 2, Supplementary Fig.6) showed that the dynamics of the 
medRxiv preprint doi: https://doi.org/10.1101/2021.03.06.21252603; this version posted March 8, 2021. The copyright holder for this preprint (which was not certified by peer review) is the author/funder, who has granted medRxiv a license to display the preprint in perpetuity. It is made available under a CC-BY-NC-ND 4.0 International license.

vaccine-specific response in both serum and breastmilk stabilized at 2D14, since the foldchange at 2D14 was not significantly higher than that at the preceding time point.

Finally, we evaluated the fraction of neutralizing antibodies in breastmilk with a previously developed in vitro competitive-blocking assay ${ }^{11}$. Both anti-spike $\lg G$ and $\lg A$ in the breastmilk of all participants exhibited a potential neutralization capacity [on average, $13 \%$ of the vaccine-specific antibodies were blocked in the assay (Supplementary Fig. 7]. Of note, a recent publication ${ }^{6}$ reported that only $62 \%$ of breastmilk samples (containing antibodies) from women with COVID-19 were found to have neutralizing capacity in vitro.

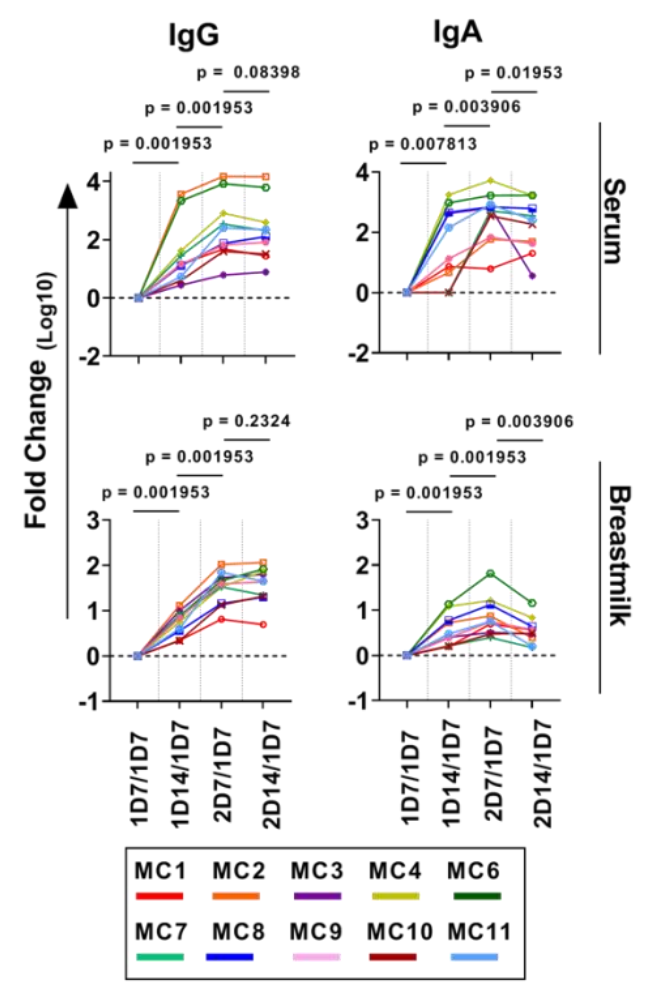

Fig. 2 Dynamics of the vaccine-specific antibody response and the antibody neutralization capacity. Fold-changes in antibody titers compared to the first time point are plotted by patient. Comparisons between the fold-change in vaccine-specific IgG and IgA antibodies were made using the Wilcoxon signed-rank test; $\mathrm{P}<0.05$ was considered statistically significant. Y-axis units are fold-change on a logarithmic scale.

The importance of breastfeeding in early infancy is highlighted by the strong correlation between breastfeeding and the overwhelming decline in risks of infection and 
medRxiv preprint doi: https://doi.org/10.1101/2021.03.06.21252603; this version posted March 8, 2021. The copyright holder for this preprint (which was not certified by peer review) is the author/funder, who has granted medRxiv a license to display the preprint in perpetuity. It is made available under a CC-BY-NC-ND 4.0 International license .

infection-associated morbidity and mortality ${ }^{12,13}$ : Breastfeeding has been associated with a decrease in the number of cases of respiratory illness ${ }^{14}$, a decreased risk of hospitalization for respiratory diseases ${ }^{15,16}$, and protection against a wide range of infections that may colonize the gut ${ }^{17,18}$. Reported cases of COVID-19 patients who experienced GI -related symptoms ${ }^{19}$ and the detection of viral RNA in stool specimens ${ }^{20}$ suggest a possible fecaloral transmission route ${ }^{21}$.

In summary, the study provides evidence for the rapid production of vaccine-specific antibodies, both IgA and IgG. Moreover, neutralizing capacity was observed in all samples. This study also indicates the potential protection of breastfed infants by administration of the BNT162b2 COVID-19 vaccine to the breastfeeding mother.

\section{Acknowledgements}

This work was supported by the Israeli Ministry of Health (MOH) grant \#3-17162)

\section{Contributions}

The study was initiated by M.R.F., A.M. and Y.W. Sample collection and processing was carried out by M.R.F., A.K., Y.D. Experiments were carried out by A.K., Y.B. and Y.D. The original manuscript draft was written by M.R.F., A.K., A.M. and Y.W. Review and editing of the manuscript were carried out by M.R.F., A.K., Y.B., Y.D., R.L., Y.Y., A.M. and Y.W.

\section{References}

1 Rosen, B., Waitzberg, R. \& Israeli, A. Israel's rapid rollout of vaccinations for COVID19. Isr J Health Policy Res 10, 6, doi:10.1186/s13584-021-00440-6 (2021).

2 CDC's COVID-19 Vaccine Rollout Recommendations: https://www.cdc.gov/coronavirus/2019-ncov/vaccines/recommendations.html. (Centers of Disease Control and Prevention, 2021). 
medRxiv preprint doi: https://doi.org/10.1101/2021.03.06.21252603; this version posted March 8, 2021. The copyright holder for this preprint (which was not certified by peer review) is the author/funder, who has granted medRxiv a license to display the preprint in perpetuity. It is made available under a CC-BY-NC-ND 4.0 International license .

3 Vaccinating Pregnant and Lactating Patients Against COVID-19. ACOG practice advisory. Available at: https://www.acog.org/clinical/clinical-guidance/practiceadvisory/articles/2020/12/vaccinating-pregnant-and-lactating-patients-againstcovid-19. (2020).

Dagan, N. et al. BNT162b2 mRNA Covid-19 Vaccine in a Nationwide Mass Vaccination Setting. N Engl J Med, doi:10.1056/NEJMoa2101765 (2021). Fox, A. et al. Robust and Specific Secretory IgA Against SARS-CoV-2 Detected in Human Milk. iScience 23, 101735, doi:10.1016/j.isci.2020.101735 (2020).

6 Pace, R. M. et al. Characterization of SARS-CoV-2 RNA, Antibodies, and Neutralizing Capacity in Milk Produced by Women with COVID-19. mBio 12, doi:10.1128/mBio.03192-20 (2021).

7 Lebrão, C. W. et al. Early Identification of IgA Anti-SARSCoV-2 in Milk of Mother With COVID-19 Infection. J Hum Lact 36, 609-613, doi:10.1177/0890334420960433 (2020).

8 Adhikari, E. H. \& Spong, C. Y. COVID-19 Vaccination in Pregnant and Lactating Women. Jama, doi:10.1001/jama.2021.1658 (2021).

9 Update on Immunization and Pregnancy: Tetanus, Diphtheria, and Pertussis Vaccination. Committee on Obstetric Practice. Available at: https://www.acog.org/clinical/clinical-guidance/committeeopinion/articles/2017/09/update-on-immunization-and-pregnancy-tetanusdiphtheria-and-pertussis-vaccination

10 Marchant, A. et al. Maternal immunisation: collaborating with mother nature. Lancet Infect Dis 17, e197-e208, doi:10.1016/s1473-3099(17)30229-3 (2017).

11 Vaisman-Mentesh, A. et al. Molecular Landscape of Anti-Drug Antibodies Reveals the Mechanism of the Immune Response Following Treatment With TNF $\alpha$ Antagonists. Front Immunol 10, 2921, doi:10.3389/fimmu.2019.02921 (2019).

12 Victora, C. G. et al. Breastfeeding in the 21st century: epidemiology, mechanisms, and lifelong effect. Lancet 387, 475-490, doi:10.1016/s0140-6736(15)01024-7 (2016).

13 Sacha, C. R. et al. Restricted isotype, distinct variable gene usage, and high rate of gp120 specificity of HIV-1 envelope-specific B cells in colostrum compared with those in blood of HIV-1-infected, lactating African women. Mucosal Immunol 8, 316326, doi:10.1038/mi.2014.69 (2015).

14 Schlaudecker, E. P. et al. IgA and neutralizing antibodies to influenza a virus in human milk: a randomized trial of antenatal influenza immunization. PLoS One 8, e70867, doi:10.1371/journal.pone.0070867 (2013).

15 Bachrach, V. R., Schwarz, E. \& Bachrach, L. R. Breastfeeding and the risk of hospitalization for respiratory disease in infancy: a meta-analysis. Arch Pediatr Adolesc Med 157, 237-243, doi:10.1001/archpedi.157.3.237 (2003).

16 Jang, M. J. et al. Positive association of breastfeeding on respiratory syncytial virus infection in hospitalized infants: a multicenter retrospective study. Clin Exp Pediatr 63, 135-140, doi:10.3345/kjp.2019.00402 (2020).

17 Duijts, L., Jaddoe, V. W., Hofman, A. \& Moll, H. A. Prolonged and exclusive breastfeeding reduces the risk of infectious diseases in infancy. Pediatrics 126, e1825, doi:10.1542/peds.2008-3256 (2010).

18 Sadeharju, K. et al. Maternal antibodies in breast milk protect the child from enterovirus infections. Pediatrics 119, 941-946, doi:10.1542/peds.2006-0780 (2007). 
medRxiv preprint doi: https://doi.org/10.1101/2021.03.06.21252603; this version posted March 8, 2021. The copyright holder for this preprint (which was not certified by peer review) is the author/funder, who has granted medRxiv a license to display the preprint in perpetuity. It is made available under a CC-BY-NC-ND 4.0 International license .

19 Buscarini, E. et al. GI symptoms as early signs of COVID-19 in hospitalised Italian patients. Gut 69, 1547-1548, doi:10.1136/gutjnl-2020-321434 (2020).

20 Chen, Y. et al. The presence of SARS-CoV-2 RNA in the feces of COVID-19 patients. J Med Virol 92, 833-840, doi:10.1002/jmv.25825 (2020).

21 Hindson, J. COVID-19: faecal-oral transmission? Nat Rev Gastroenterol Hepatol 17, 259, doi:10.1038/s41575-020-0295-7 (2020). 